\title{
Tissue-specific element profiles in Scots pine (Pinus sylvestris L.) needles
}

\author{
Paula Pongrac ${ }^{1,2}$ - Edita Baltrenaite ${ }^{3} \cdot$ Primož Vavpetič $^{1} \cdot$ Mitja Kelemen $^{1} \cdot$ Aleš Kladnik $^{2} \cdot$ Bojan Budič $^{4} \cdot$ \\ Katarina Vogel-Mikuš ${ }^{1,2} \cdot$ Marjana Regvar $^{2} \cdot$ Pranas Baltrenas $^{3} \cdot$ Primož Pelicon $^{1}$
}

Received: 18 May 2018 / Accepted: 4 September 2018 / Published online: 11 September 2018

(c) The Author(s) 2018

\begin{abstract}
Key message Element profile signatures of needle tissues differentiated four tissues: epidermis (main contributor: calcium), endodermis (main contributors: magnesium, sulphur and manganese), mesophyll (main contributor: potassium), and transfusion parenchyma (main contributor: zinc).

Abstract Distribution of elements in cross-sections of Scots pine (Pinus sylvestris L.) needles was investigated using microproton-induced X-ray emission. Tissue-specific distributions of magnesium ( $\mathrm{Mg}$ ), sulphur (S), calcium (Ca), phosphorus $(\mathrm{P})$, potassium $(\mathrm{K})$, chlorine $(\mathrm{Cl})$, manganese $(\mathrm{Mn})$, iron $(\mathrm{Fe})$, zinc $(\mathrm{Zn})$, aluminium $(\mathrm{Al})$ and silicon $(\mathrm{Si})$ were resolved in a quantitative manner. Distribution maps and tissue-specific concentrations revealed the largest concentration of Ca in epidermis, of $\mathrm{Mg}, \mathrm{S}$ and $\mathrm{Mn}$ in endodermis, of $\mathrm{K}$ in mesophyll and phloem and of $\mathrm{Zn}$ in transfusion parenchyma. Phosphorus, $\mathrm{Cl}, \mathrm{Fe}, \mathrm{Al}$ and $\mathrm{Si}$ did not exhibit apparent tissue-specific distribution. Inverse allocation of $\mathrm{P}$ and $\mathrm{Ca}$ was observed, a likely mechanism to prevent their precipitation. Taking the area of tissues into account, relative element distribution calculations indicated that mesophyll contained the majority of the elements studied, except $\mathrm{Ca}$, which predominated in the epidermis ( $79 \%$ of total Ca concentration) and $\mathrm{Mn}$, which predominated in the endodermis (40\% of total Mn concentration). When considering a complete element profile of a particular tissue, four clusters were differentiated, which generally supported single-element observations. The first cluster differentiated mesophyll, xylem, phloem, transfusion tracheids and Strasburger cells with predominance of $\mathrm{K}$, the second cluster differentiated epidermis on the basis of $\mathrm{Ca}$, the third cluster differentiated endodermis with contributions from $\mathrm{Mg}, \mathrm{S}$ and $\mathrm{Mn}$, and the fourth cluster differentiated transfusion parenchyma with contribution from $\mathrm{Zn}$. Information on tissue-specific-element allocations will complement structural and functional knowledge of needle tissues and advance our understanding of element/nutrient transfers in Scots pine.
\end{abstract}

Keywords Mineral nutrition $\cdot$ X-ray fluorescence $\cdot$ Endodermis $\cdot$ Transfusion tissue $\cdot$ Element signatures

\section{Introduction}

Communicated by Koike.

Paula Pongrac

paula.pongrac@gmail.com

1 Jožef Stefan Institute, Jamova cesta 39, 1000 Ljubljana, Slovenia

2 Biotechnical Faculty, University of Ljubljana, Jamnikarjeva ulica 101, 1000 Ljubljana, Slovenia

3 Vilnius Gediminas Technical University, Sauletekio al. 11, Vilnius 10221, Lithuania

4 National Institute of Chemistry, Hajdrihova ulica 19, 1000 Ljubljana, Slovenia
Leaf morphologies and anatomies differ substantially between plant species as a consequence of their phylogenetic origin and adaptation to environmental pressures. Common denominator to all leaves is the presence of protective epidermis, photosynthetically active mesophyll and water-mineral-and-sugar-transferring vascular bundles. Unlike in angiosperm leaves, in majority of gymnosperm leaves (needles), two distinctive structures separate centrally positioned vascular bundles from mesophyll: endodermis and transfusion tissue (Liesche et al. 2011). Endodermis is a layer of cells, whose cell walls sometimes contain Casparian strip (Lersten 1997) and functions similarly to endodermal barrier in roots, namely preventing uncontrolled apoplastic 
movement of solutes, although in roots the Casparian strip is less permeable (Wu et al. 2005). In addition, endodermis has been proposed to prevent ice formation (Kuang et al. 2007; Roden et al. 2009) and to biophysical properties related to needle flexibility (Meicenheimer et al. 2008). In conjunction with transfusion tissue, endodermis also contributes to phloem loading (Liesche et al. 2011; Carvalho et al. 2018; Liesche and Schulz 2018). Transfusion tissue comprises specialised cells of transfusion tracheids and transfusion parenchyma cells. Transfusion tracheids are dead cells and reportedly participate in xylem unloading, while transfusion parenchyma forms bridges of living cells between the endodermis and Strasburger cells, which flank phloem cells (Liesche et al. 2011). In addition, gymnosperm needles are characterised by a variable number of resin ducts positioned on the periphery of the thick-walled cells of mesophyll and epidermal cells with thick cutinized outer walls (Liesche et al. 2011).

Mineral element composition of angiosperm plants is controlled by evolutionary processes and the environment (Watanabe et al. 2007; Neugebauer et al. 2018). Less systematic work has been performed on gymnosperms, although several studies have evaluated mineral element composition of the needles and the environmental factors affecting it. For example, soil alkalisation level (Mandre 2009), humus content (Merilä and Derome 2008) and sulphur (S) and pollution gradients (Rautio and Huttunen 2003) have been shown to affect mineral element composition of needles. Additionally, variability in concentrations of mineral elements in needles have been related to the needle age (Lamppu and Huttunen 2003; Kuang et al. 2007) and the concentrations of essential and non-essential elements have been shown to differ along the needle length (Giertych et al. 1997). Earlier study on mineral element distributions in white pine (Pinus strobus $\mathrm{L}$.) needle detected calcium $(\mathrm{Ca})$, manganese $(\mathrm{Mn})$, iron $(\mathrm{Fe})$, copper $(\mathrm{Cu})$ and zinc $(\mathrm{Zn})$ in the epidermis, endodermis and transfusion tissue, magnesium $(\mathrm{Mg})$ was detected in endodermis, while potassium $(\mathrm{K})$, phosphorus $(\mathrm{P}), \mathrm{S}$ and chlorine $(\mathrm{Cl})$ were evenly distributed (Hodson and Sangster 2002). In spruce [Picea abies (L.) Karst] endodermis was rich in Mg and K (Hodson and Sangster 1998). Tissue-specific distribution in needles of Araucaria angustifolia (Bertol.) Kuntze, devoid of endodermis and transfusion tissue, was affected by nutrient deficiencies in the soil (Barbosa et al. 2017). So far, however, mineral element composition has not been quantified and element distributions have not been mapped in a whole-needle cross-section. Therefore, the aim of our study was (1) to resolve tissue-specific mineral element profiles in needles of Scots pine (Pinus sylvestris L.) using quantitative mapping technique (micro-particle induced X-ray emission, micro-PIXE), (2) to determine relative element distribution in these needles by taking the cross-sectional area of needle tissues into account, and (3) to test whether tissue-specific element profiles can be used to differentiate needle tissues by $k$-means clustering. Scots pine needles were used because of their widespread use in biomonitoring of heavy metal pollution (Bertolotti and Gialanella 2014).

\section{Materials and methods}

\section{Plant material}

The collection site of needles was in the Neris Regional Park (N 54.719946, E 25.043057), a $100 \mathrm{~km}^{2}$ of natural-cultural protected area in Lithuania. The location of the collection site was $35 \mathrm{~km}$ away from the nearest town. Three healthy looking Scots pine (Pinus sylvestris $\mathrm{L}$.) trees were selected throughout the plot $(10 \times 10 \mathrm{~m})$ of the study area for the sampling as previously described (Pundyte et al. 2011). A composite sample was prepared by mixing equal amounts (300 pairs of needles from each tree), which were kept in paper bags until analyses.

\section{Sectioning needles for element localisation analysis}

The needles were detached from twigs and sectioned with a razor blade to shorter pieces. The middle parts of needles were transferred into tissue freezing medium (Jung, Leica) and frozen in liquid nitrogen (Vogel-Mikuš et al. 2014). Plant material was transversally sectioned to $50 \mu \mathrm{m}$ thickness with a Leica CM3050 cryotome (Leica, Bensheim, Germany) at $-25{ }^{\circ} \mathrm{C}$. Sections were placed in custom-made aluminium (Al) holders, covered with a stainless-steel fitting cover to ensure the flatness of the sections and transferred to a freeze dryer (Alpha 2-4 Christ, Osterode am Harz, Germany) via cryo-transfer-assembly cooled by liquid nitrogen. Sections were freeze-dried at $-25^{\circ} \mathrm{C}$ and a pressure of 0.240 mbar for 3 days. Dry sections were sandwiched between two thin layers of Pioloform foil stretched on $\mathrm{Al}$ holders and photographed using Axioskop 2 MOT microscope (Carl Zeiss, Göttingen, Germany), equipped with an Axiocam MRc colour digital camera (Carl Zeiss), using AxioVision 4.1 software using bright field and UV excitation $(365 \mathrm{~nm})$.

\section{Bulk element analysis}

Remaining needle material was dried in the oven at $60{ }^{\circ} \mathrm{C}$ for 3 days. Needles were ground with liquid nitrogen using pestle and a mortar, wet digested and analysed for bulk concentrations of $\mathrm{Mg}, \mathrm{S}, \mathrm{Ca}, \mathrm{P}, \mathrm{K}, \mathrm{Mn}, \mathrm{Fe}, \mathrm{Cu}, \mathrm{Zn}$, boron (B), nickel (Ni), chlorine $(\mathrm{Cl})$, sodium $(\mathrm{Na}), \mathrm{Al}$, silicon $(\mathrm{Si})$, chromium $(\mathrm{Cr})$, cadmium $(\mathrm{Cd})$ and lead $(\mathrm{Pb})$ 
using inductively coupled plasma-mass spectroscopy as described elsewhere (Pongrac et al. 2013).

\section{Mapping of element distribution in needle cross-sections and data processing}

Tissue-specific distribution of $\mathrm{Mg}, \mathrm{S}, \mathrm{Ca}, \mathrm{P}, \mathrm{K}, \mathrm{Cl}, \mathrm{Mn}$, $\mathrm{Fe}, \mathrm{Zn}, \mathrm{Al}$ and $\mathrm{Si}$ was obtained using micro-particleinduced X-ray emission (micro-PIXE) on seven needle cross-sections. Micro-PIXE analysis was performed at the nuclear microprobe of the Jožef Stefan Institute as previously described (Lyubenova et al. 2012; Pelicon et al. 2014; Vavpetič et al. 2015; Detterbeck et al. 2016). Simultaneously, an on-off axis scanning transmission ion microscopy was performed to determine beam exit energy from the sample, related to the sample local tissue density (Pallon et al. 2004; Vavpetič et al. 2013). The micro-PIXE spectra were analysed and numerical matrices (pixel-by-pixel concentration matrices), distribution and co-localisation maps were generated by GeoPIXE II software package (Ryan 2000). Distribution maps were filtered using smooth (Gaussian function, standard deviation 1.5) and edge enhance (Roberts function) filters in GeoPIXEII. Element concentrations were extracted from different tissues using ImageJ software (Abràmoff et al. 2004) as described previously (Vogel-Mikuš et al. 2014). In a whole-needle cross-section (resolution: $6.8 \mu \mathrm{m}$ ), the areas of epidermis, mesophyll, endodermis and central cylinder were distinguished and element concentrations were extracted by encircling selected tissues. Relative element distribution in particular tissue was calculated on the basis of element concentration in this tissue and the relative area proportion of this tissue in the needle, which were determined by measuring area of particular tissue in ImageJ to be: epidermis $29 \%$, mesophyll $41 \%$, endodermis $10 \%$ and central cylinder $17 \%$. In the zoomed region of the central cylinder (resolution: $2.2 \mu \mathrm{m}$ ), the element concentrations were retrieved by point extraction $(n=15-30$ points from the following tissues: epidermis, mesophyll, endodermis, transfusion parenchyma, sclerenchyma, xylem, phloem, transfusion tracheids and Strasburger cells). Averages and standard errors were calculated and graphs were generated in Excel or in SigmaPlot version 13.0 (Systat Software, San Jose, CA, USA). For the separation of tissues based on their complete element profiles, element concentration in particular needle tissue were $z$-normalized (to eliminate the differences in concentration ranges) and $k$-means clustering with random initialization was performed on cumulative $z$-normalized data. Clustering analysis and hyperspectral image depicting tissues with distinctive element profile were generated in Orange 3.13 software (Toplak et al. 2017).

\section{Results and discussion}

\section{Bulk element concentration in Scots pine needles}

Total concentrations of essential, beneficial and nonessential elements measured in Scots pine needles and the published sufficiency ranges are shown in Table 1 . Comparison of measured concentrations with ranges proposed as sufficient for Scots pine seedlings (Ingestad 1962) revealed that only concentration of $\mathrm{Mg}$ was in sufficiency range, concentrations of $\mathrm{K}$ and $\mathrm{S}$ were below sufficiency threshold, concentration of $\mathrm{P}$ was borderline sufficient and concentrations of $\mathrm{Ca}$ were above sufficiency threshold. Braekke and Salih (2002) proposed sufficiency values without upper ranges for Scots pine, and comparison with our measurements revealed sufficient concentrations of micronutrients $\mathrm{B}, \mathrm{Mn}, \mathrm{Fe}, \mathrm{Cu}$ and $\mathrm{Zn}$ and of macronutrients $\mathrm{Mg}$ and $\mathrm{S}$, and concentrations of $\mathrm{P}$ and $\mathrm{K}$ bellow sufficiency threshold. Sufficiency ranges proposed for the Scots pine (Ingestad 1962; Braekke and; Salih 2002) do not differ substantially from those suggested for crops by White and Brown (2010), which enabled us to conclude on the remaining essential, beneficial and non-essential elements measured in Scots pine needles. The comparison revealed that $\mathrm{Cl}$ was in sufficiency range, while $\mathrm{Ni}$ was above sufficiency threshold but still below toxicity threshold (proposed at 20-30 $\mathrm{mg} \mathrm{kg}^{-1}$ ) (White and Brown 2010). Of the beneficial elements, Na was below threshold considered to be beneficial, while $\mathrm{Al}$ was above the proposed threshold. Of non-essential elements, concentration of $\mathrm{Cr}$ was above the set threshold for toxicity, while concentrations of $\mathrm{Cd}$ and $\mathrm{Pb}$ were below this threshold. Altogether, needle element profiles of our Scots pines point to $S$ and $\mathrm{K}$ deficiency accompanied by $\mathrm{Al}$ and $\mathrm{Cr}$ toxicity. However, no visible deficiency or toxicity symptoms were present indicating that the concentrations measured sufficed for normal physiological processes. For Mn, concentrations around $250 \mathrm{mg} \mathrm{kg}^{-1}$ dry matter were reported as adequate for maximal growth of Scots pine seedlings (Kavvadias and Miller 1999), therefore, the measured value, which was well above sufficiency threshold proposed by (White and Brown 2010) should not be considered toxic for Scots pine trees studied. Different environmental factors have been shown to affect mineral nutrition of gymnosperms. For example, $\mathrm{P}, \mathrm{K}, \mathrm{Ca}$ and $\mathrm{Mn}$ deficiencies and $\mathrm{Al}$ toxicity have been linked to air pollution in Masson's pine (Pinus massoniana L.) (Kuang et al. 2007). However, relatively low $\mathrm{Pb}$ and $\mathrm{Cd}$ concentrations measured in our study, does not indicate considerable industrial or traffic based air pollution. In addition, the location of study area in the Neris Regional Park, where economic activities are limited, excludes any anthropogenic impact. On the other 
Table 1 Measured concentrations $\left(\mathrm{mg} \mathrm{kg}^{-1}\right.$ dry matter) of magnesium $(\mathrm{Mg})$, sulphur (S), calcium $(\mathrm{Ca})$, phosphorus $(\mathrm{P})$, potassium $(\mathrm{K})$, manganese $(\mathrm{Mn})$, iron $(\mathrm{Fe})$, zinc $(\mathrm{Zn})$, copper $(\mathrm{Cu})$, boron (B), nickel (Ni), chlorine $(\mathrm{Cl})$, sodium $(\mathrm{Na})$, aluminium $(\mathrm{Al})$, silicon $(\mathrm{Si})$, chromium $(\mathrm{Cr})$, cadmium $(\mathrm{Cd})$ and lead $(\mathrm{Pb})$ in Scots pine needle and the published sufficiency ranges for Scots pine seedling (Ingestad 1962), for spruce and Scots pine (Brække and Salih 2002) and for crops (White and Brown 2010)

\begin{tabular}{lrlll}
\hline Element & This study & Ingestad (1962) & $\begin{array}{l}\text { Braekke and Salih } \\
(2002)\end{array}$ & White and Brown (2010) \\
\hline $\mathrm{Mg}$ & $1268 \pm 35.9$ & $1,200-1,800$ & $>800$ & $1500-3500$ \\
$\mathrm{~S}$ & $916 \pm 25.9$ & $2,000-2,500$ & $>800$ & $1000-5000$ \\
$\mathrm{Ca}$ & $4978 \pm 51.6$ & $400-3,000$ & $>700$ & $500-10,000$ \\
$\mathrm{P}$ & $1472 \pm 34.7$ & $1,500-4,000$ & $>1,800$ & $2000-5000$ \\
$\mathrm{~K}$ & $3728 \pm 356$ & $9,000-16,000$ & $>6,000$ & $5000-40,000$ \\
$\mathrm{Mn}$ & $175 \pm 10.1$ & & $>15$ & $10-20$ \\
$\mathrm{Fe}$ & $198 \pm 8.84$ & & $>20$ & $50-150$ \\
$\mathrm{Cu}$ & $8.3 \pm 0.53$ & & $>2$ & $1-5$ \\
$\mathrm{Zn}$ & $42.0 \pm 2.57$ & & $>12$ & $15-30$ \\
$\mathrm{~B}$ & $12.3 \pm 0.89$ & & $>8$ & $5-100$ \\
$\mathrm{Ni}$ & $9.78 \pm 0.05$ & & & $0.1-1$ \\
$\mathrm{Cl}$ & $320 \pm 6.11$ & & & $100-6000$ \\
$\mathrm{Na}^{\mathrm{a}}$ & $24 \pm 4.56$ & & & $2000-5000$ \\
$\mathrm{Al}$ & $\mathbf{3 8 7}$ & & & $40-200$ \\
$\mathrm{Si}^{\mathrm{a}}$ & $2166 \pm 314$ & & nd \\
$\mathrm{Cr}^{\mathrm{b}}$ & $\mathbf{1 0 . 6} \pm \mathbf{0 . 0 3}$ & & $1-2$ \\
$\mathrm{Cd}^{\mathrm{b}}$ & $0.11 \pm 0.00$ & & $5-10^{* *}$ \\
$\mathrm{~Pb}^{\mathrm{b}}$ & $1.37 \pm 0.04$ & & $10-20^{* *}$ \\
\hline
\end{tabular}

Concentrations below sufficiency threshold are highlighted in italics and those above toxicity threshold are highlighted in bold

$n d$ not determined

${ }^{\mathrm{a} B}$ Beneficial element

${ }^{b}$ Not essential element (values indicate proposed ranges where toxicity occurs) hand, large $\mathrm{Al}, \mathrm{Fe}$ and $\mathrm{Mn}$ concentrations in needles indicate substantial soil acidity, which is known to increase bioavailability of these three elements in soils (Bromfield et al. 1983; Taiz and Zeiger 2006). Soil analyses were beyond the aims of our study, therefore, any substantiated conclusions cannot be made.

\section{Distribution of tissues in needle cross-section}

Middle parts of Scots pine needles were cryo-fixed, cryosectioned and freeze-dried. In these freeze-dried sections the following tissues were distinguished: epidermis, mesophyll, endodermis, resin duct, phloem, xylem, transfusion parenchyma, transfusion tracheids, Strasburger cells and sclerenchyma (Fig. 1) (Liesche et al. 2011). In the autofluorescence image obtained by UV excitation, chlorophyll fluoresces in red (dominating in mesophyll and transfusion parenchyma cells), while the blue fluorescence represents a combination of suberin and lignin in the cells walls (Donaldson and Williams 2018), apparent in all the remaining tissues. Increased lignification and suberisation is visible in the radial cell walls of the endodermal cells (Fig. 1a), resembling a Casparian strip. Sclerenchyma in the central cylinder and surrounding resin ducts are clearly seen in the bright-field image (Fig. 1b).

\section{Tissue-specific distribution of elements in needle cross-section}

The needle cross-sections were analysed using microPIXE and quantitative distribution maps of $\mathrm{Mg}, \mathrm{S}, \mathrm{Ca}, \mathrm{P}$, $\mathrm{K}, \mathrm{Cl}, \mathrm{Mn}, \mathrm{Fe}, \mathrm{Zn}, \mathrm{Al}$ and $\mathrm{Si}$ in a representative wholeneedle cross-section (resolution: $6.8 \mu \mathrm{m}$ ) are shown in Fig. 2, while zoomed area of the central cylinder (resolution: $2.2 \mu \mathrm{m}$ ) is shown in Fig. 3. A tissue-specific distribution of elements is apparent from these distribution maps, with most striking allocation of $\mathrm{Ca}$ to epidermis and a substantial allocation of $\mathrm{Mg}, \mathrm{S}$ and $\mathrm{Mn}$ to endodermis, which could be due to transport limitations for these mineral elements connected with the existence of the extracellular diffusion barrier, i.e., Casparian strip. In angiosperm leaves, bundle sheath cells play a similar metabolic role (Leegood 2008; Wigoda et al. 2017), although they generally lack Casparian strip. As argued in the introduction, the needle endodermis in gymnosperms resembles the root endodermis both in the morphology as well as in function: it is a bottleneck for outward transport of water and mineral nutrients (Liesche et al. 2011) and it contributes to the regulation of carbohydrate export from the needles (Liesche and Schulz 2018). Surprisingly, xylem unloading 

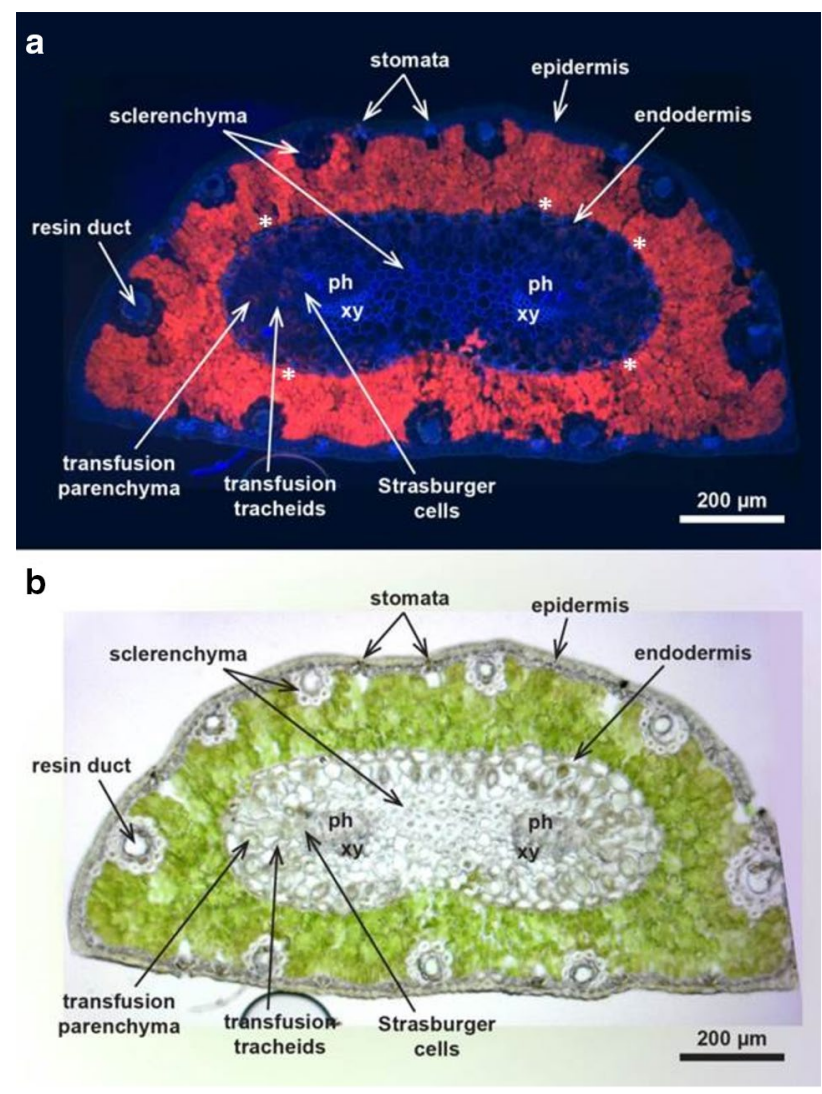

Fig. 1 Scots pine needle cross-section photographed using a light microscope with UV excitation at $365 \mathrm{~nm}$ resulting in tissue autofluorescence (a), the same section photographed in the bright field (b). $x$ xylem, $p h$ phloem, asterisks indicate the radial thickening of the endodermal cells resembling the Casparian strip

and phloem loading in gymnosperms remain substantially understudied mechanisms (Liesche and Schulz 2018).

Distribution maps in Figs. 2 and 3 were used to extract element concentrations from individual tissues. Tissuespecific element concentrations from Fig. 2 were used to calculate relative element distribution (Fig. 4) in epidermis, mesophyll, endodermis and central cylinder by taking into account the surface proportion of the tissue in the needle. Detailed distribution map from Fig. 3 was used to depict tissue-specific element concentration (Fig. 5) for individual transfusion tissues as well. As observed in the distribution maps, most striking was the Mn allocation to endodermis in Scots pine needle, with on average $40 \%$ of total $\mathrm{Mn}$ in the needle found in this tissue and with an average concentration of $8000 \mathrm{mg} \mathrm{kg}^{-1}$ dry matter (Figs. 4, $5)$. This indicates tolerance to extreme Mn concentrations of endodermal cells. Manganese tolerance in plants has been attributed to Mn binding to oxalate (Dou et al. 2009), which may have taken place in the endodermis of Scots pine needle. Although we have no data for oxalate concentration in different needle tissues, the presence of oxalate in endodermis may be inferred from large Ca concentrations in this tissues, since oxalate is a typical $\mathrm{Ca}$ ligand (Franceschi and Nakata 2005). Numerous reports on Ca oxalate crystals in conifer needles (Fink 1991a) further support this indirect conclusion. Alternatively, Mn could be bound to S-compounds (note increased $\mathrm{S}$ allocation to endodermis). Further studies will have to be performed to answer these questions. We can, however, hypothesise that immobilisation of $\mathrm{Mn}$ in endodermis prevents excessive $\mathrm{Mn}$ concentration in mesophyll, where it may negatively interfere with photosynthetic processes (Fernando and Lynch 2015). In spruce needles, large Mg and $\mathrm{K}$ concentrations have been found in mature endodermis cells, where $\mathrm{P}$ and $\mathrm{S}$ were suggested to represent the major part of the potentially inorganic counter-ions for this increased $\mathrm{Mg}$ and K concentrations (Stelzer et al. 1990). Similarly, endodermis of Scots pine needle was enriched in $\mathrm{Mg}$ and $\mathrm{S}$, but not in $\mathrm{K}$ and $\mathrm{P}$ (Figs. 2, 3, 4, 5), indicating that major inorganic anion for the endodermis enrichment of $\mathrm{Mg}$ and $\mathrm{Mn}$ is $\mathrm{S}$ (as sulphate) and presumably oxalic acid, which has been previously implicated in Mn tolerance (Dou et al. 2009). Additionally, charge balance may be controlled by $\mathrm{Cl}$, however, the endodermis contained only $11 \%$ of the total $\mathrm{Cl}$ in the needle (Fig. 4), hence this may not suffice for effective counter balance; or by nitrates and other organic anions (these were not measured in this study). It appears that the endodermal cells may in addition to having Mn tolerance character serve as a storage buffer for maintaining homeostasis of $\mathrm{Mg}$ and $\mathrm{S}$ nutrition, as proposed by Stelzer et al. (1990).

The largest concentrations of $\mathrm{Ca}$ and the largest proportion of Ca were found in epidermis (Figs. 4, 5), where its deposition was irregular with numerous intermissions, presumably stomatal apertures in the epidermis (stomata can be seen in Fig. 1). Calcium allocation to epidermis is a consequence of this element being transported mainly with the transpiration stream (Hawkesford et al. 2012) and whose distribution can be restricted by Casparian strip at the endodermis. Similarly, the largest Ca concentration in needle epidermis was found in white pine (Hodson and Sangster 2002) and in Scots pine and Swiss pine (P. cembra L.) (Fink 1991a). The latter two species, in contrast to other conifers, also contained $\mathrm{Ca}$ oxalate crystals in phloem parenchyma (Fink 1991a), similar to Ca hotspots seen in the vicinity of phloem tissues in our cross-section (Figs. 2, 3). In epidermis of Scots pine, Ca oxalate crystals were found intracellularly, unlike in other conifer needles, where majority of $\mathrm{Ca}$ was deposited in $\mathrm{Ca}$ oxalate crystals intercellularly in the epidermis, particularly in the cuticular layer (Fink 1991a, b). The resolution of our $\mathrm{Ca}$ distribution maps, unfortunately, does not allow discerning $\mathrm{Ca}$ oxalate crystals in our Scots pine needle cross-sections, but it suggests within-cell and cellwall allocation of $\mathrm{Ca}$ to epidermis and endodermis. 

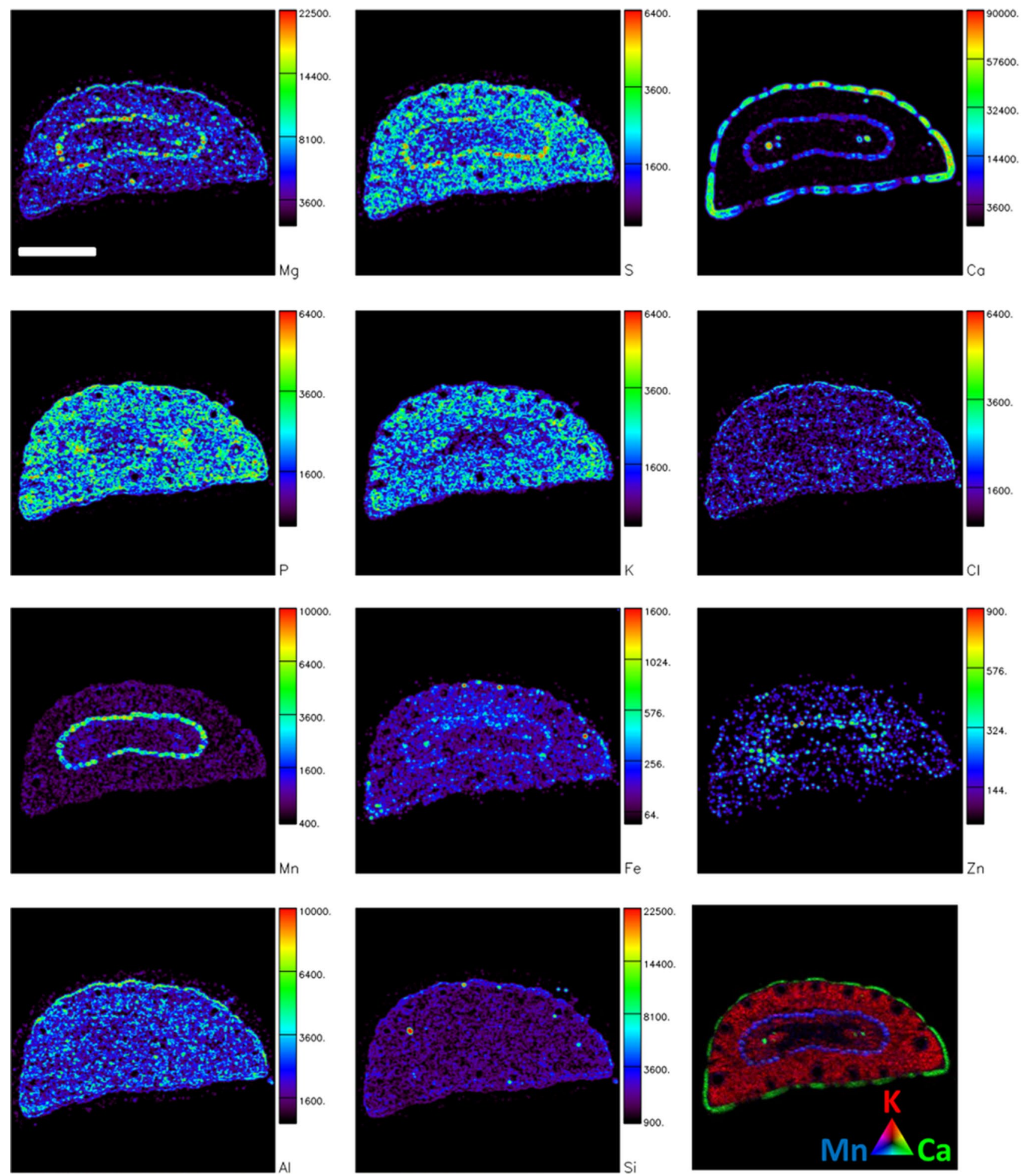

Fig. 2 Distribution maps of magnesium ( $\mathrm{Mg})$, sulphur (S), calcium $(\mathrm{Ca})$, phosphorus $(\mathrm{P})$, chlorine $(\mathrm{Cl})$, potassium $(\mathrm{K})$, manganese $(\mathrm{Mn})$, iron $(\mathrm{Fe})$, zinc $(\mathrm{Zn})$, aluminium $(\mathrm{Al})$ and silicon $(\mathrm{Si})$ and a co-locali- sation image (bottom right) of $\mathrm{K}$ (in red), $\mathrm{Ca}$ (in green) and $\mathrm{Mn}$ (in blue) in a cross-section of Scots pine needle. Colour legends to distribution maps are in $\mathrm{mg} \mathrm{kg}^{-1}$ dry matter; scale bar indicates $500 \mu \mathrm{m}$ 

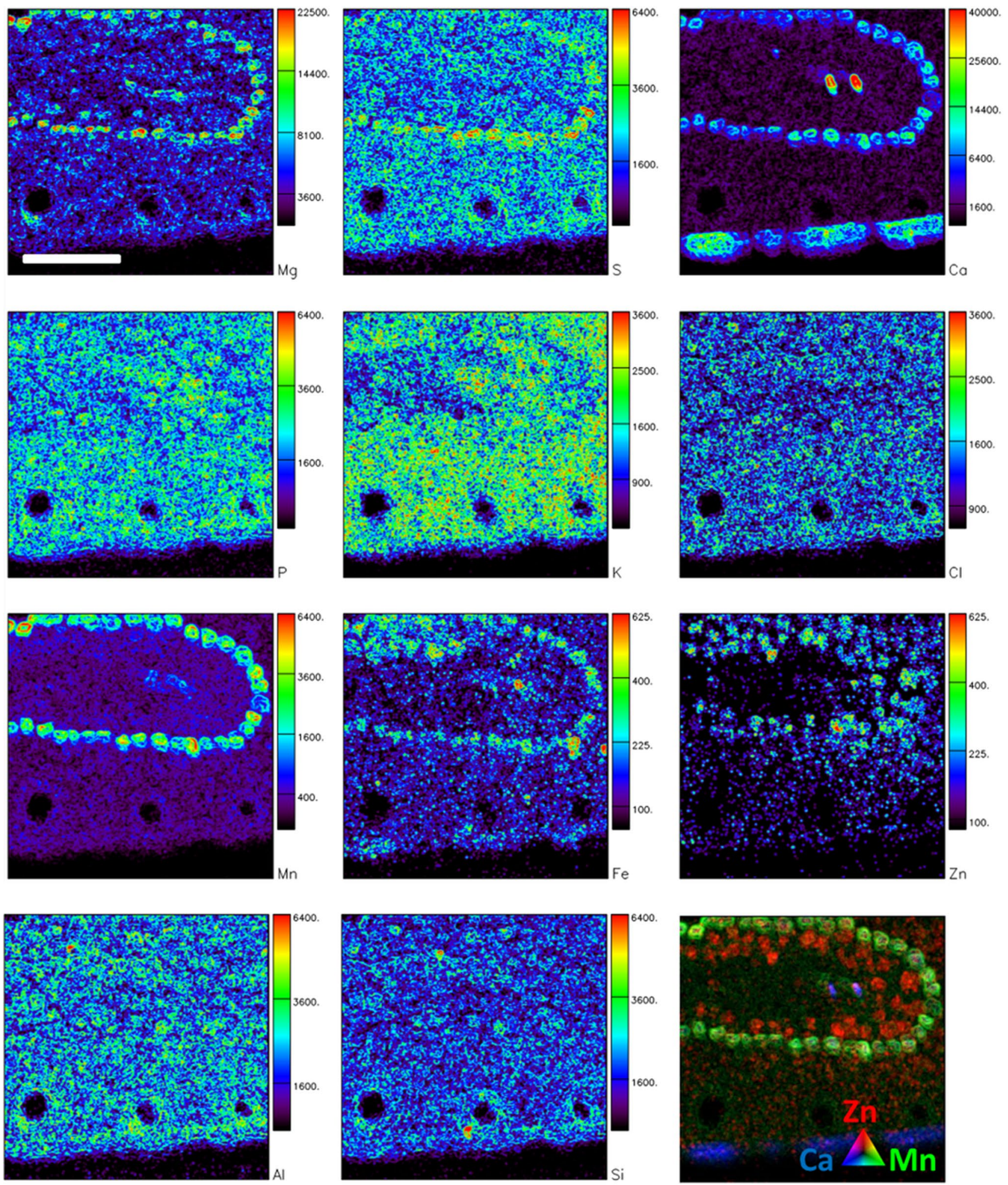

Fig. 3 Detailed distribution maps of magnesium $(\mathrm{Mg})$, sulphur $(\mathrm{S})$, calcium $(\mathrm{Ca})$, phosphorus $(\mathrm{P})$, chlorine $(\mathrm{Cl})$, potassium $(\mathrm{K})$, manganese $(\mathrm{Mn})$, iron $(\mathrm{Fe})$, zinc $(\mathrm{Zn})$, aluminium $(\mathrm{Al})$ and silicon $(\mathrm{Si})$ and a co-localisation image (bottom right) of $\mathrm{Zn}$ (in red), $\mathrm{Mn}$ (in green) and
$\mathrm{Ca}$ (in blue) in a cross-section of Scots pine needle. Colour legends to distribution maps are in $\mathrm{mg} \mathrm{kg}^{-1}$ dry matter; scale bar indicates $200 \mu \mathrm{m}$ 


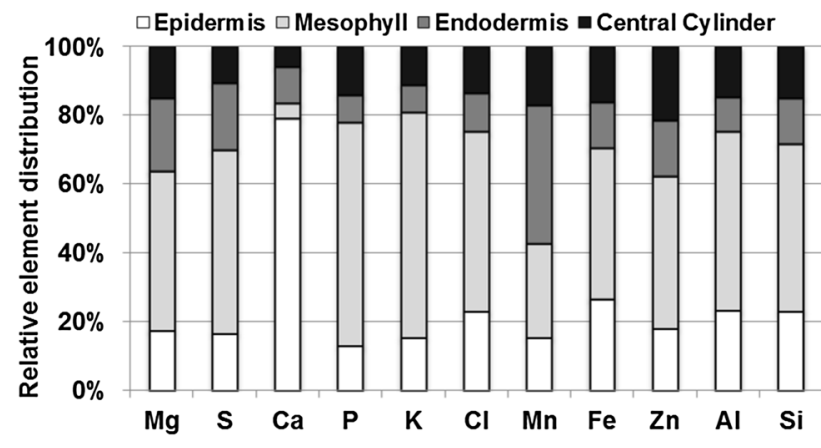

Fig. 4 Relative element profile in tissues of Scots pine needle (as percentages of total content) calculated from tissue-specific concentrations obtained by micro-PIXE mapping (distribution maps in Fig. 2) and the relative surface proportions of the needle tissues (epidermis $29 \%$, mesophyll $41 \%$, endodermis $10 \%$ and central cylinder $17 \%$ ). Elements: magnesium $(\mathrm{Mg})$, sulphur $(\mathrm{S})$, calcium $(\mathrm{Ca})$, phosphorus $(\mathrm{P})$, chlorine $(\mathrm{Cl})$, potassium $(\mathrm{K})$, manganese $(\mathrm{Mn})$, iron $(\mathrm{Fe})$, zinc $(\mathrm{Zn})$, aluminium $(\mathrm{Al})$ and silicon $(\mathrm{Si})$
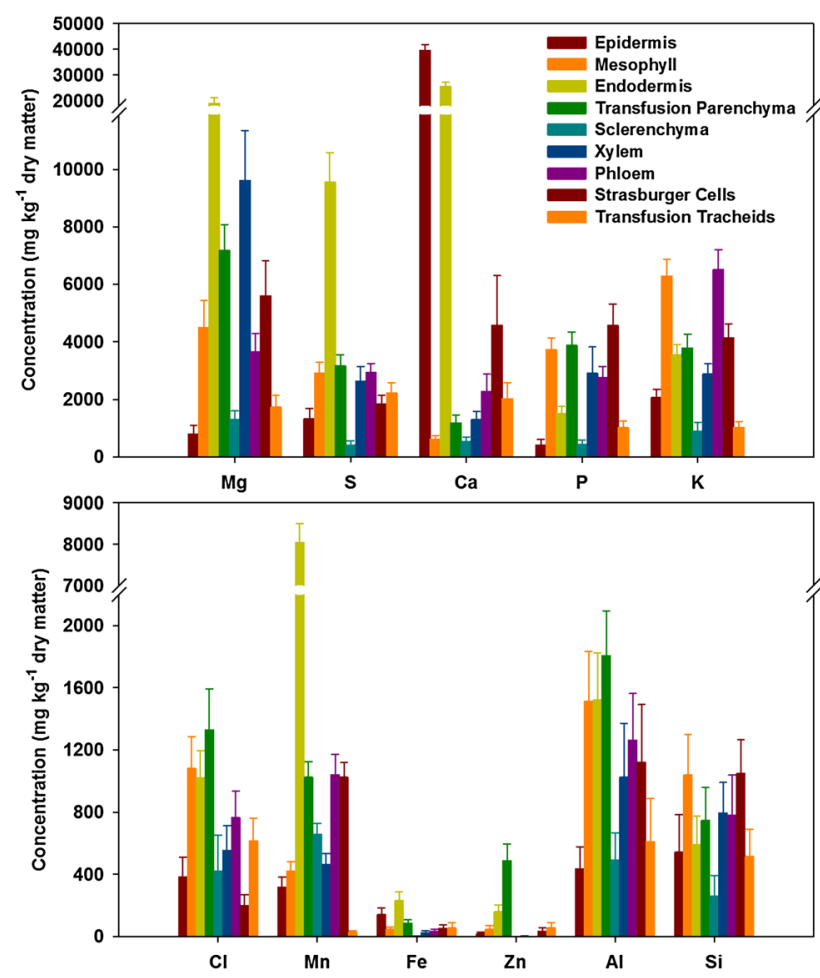

Fig. 5 Tissue-specific concentrations ( $\mathrm{mg} \mathrm{kg}^{-1}$ dry matter) of magnesium $(\mathrm{Mg})$, sulphur $(\mathrm{S})$, calcium $(\mathrm{Ca})$, phosphorus $(\mathrm{P})$, potassium $(\mathrm{K})$, chlorine $(\mathrm{Cl})$, manganese $(\mathrm{Mn})$, iron $(\mathrm{Fe})$, zinc $(\mathrm{Zn})$, aluminium (Al) and silicon $(\mathrm{Si})$ in Scots pine needle. Shown are means \pm standard errors (number of points for the extraction of concentrations from tissues in Fig. 3 was 15-30)

Potassium, $\mathrm{P}, \mathrm{S}$ and $\mathrm{Cl}$ were reported to be ubiquitously distributed in white pine needle tissue (Hodson and Sangster 2002) and this is generally in line with our results. Mesophyll was tissue of primary allocation of $\mathrm{K}, \mathrm{P}, \mathrm{S}$ and $\mathrm{Cl}$
$(65 \%, 65 \%, 53 \%$ and $52 \%$, respectively) and minimal allocation to epidermis $(8 \%, 8 \%, 19 \%$ and $11 \%$ respectively; Fig. 4). Substantial allocation of $\mathrm{P}$ to mesophyll was proposed for a typical monocotyledonous plant which contrasts $\mathrm{P}$ allocation to epidermis of dicotyledonous plants (Conn and Gilliham 2010). Inverse allocation of $\mathrm{Ca}$ [predominant allocation of $\mathrm{Ca}$ to epidermis in leaves of monocots, and predominant $\mathrm{Ca}$ allocation to mesophyll was proposed for dicotyledonous plants (Conn and Gilliham 2010)] to P, observed also in Scots pine needle, was proposed as a feasible mechanism preventing precipitation of $\mathrm{P}$ with $\mathrm{Ca}$ (White and Broadley 2003; Conn and Gilliham 2010; Hayes et al. 2018). In monocots, $\mathrm{Mg}$ and $\mathrm{S}$ were suggested to accumulate in mesophyll, while in dicots, $\mathrm{Mg}$ was reported to be located in epidermis (Conn and Gilliham 2010). There is no such generalisation made for tissue-specific allocation of elements suggested for conifers. In Scots pine needle, mesophyll was the largest pool for all elements, except for $\mathrm{Ca}$ and $\mathrm{Mn}$ (Fig. 4), which is due to mesophyll occupying the largest proportion of the needle (at $41 \%$ ). In central cylinder, where transfusion tissues are located, $\mathrm{Zn}$ dominated (22\% of total $\mathrm{Zn}$ ) and the element with the least contribution to this tissue was $\mathrm{Ca}$ (6\% of total Ca; Fig. 4).

\section{Distribution of elements in transfusion tissues}

To capture transfusion tissues in greater detail, distributions of elements in these tissues were mapped and tissue-specific distribution of elements is shown in Fig. 3. Apparent tissue-specific element profiles were utilised to distinguish transfusion tissues in central cylinder as follows: xylem was characterised by $\mathrm{Mg}$ accumulation, phloem by $\mathrm{Mn}$ and $\mathrm{K}$ accumulation, transfusion parenchyma by $\mathrm{Zn}$ accumulation, Strasburger cells by $\mathrm{P}$ accumulation and transfusion tracheids by no apparent accumulation. Similar to transfusion tracheids, resin ducts and associated sclerenchyma and the sclerenchyma in the central cylinder had the least of elements allocated when compared to other tissues (Fig. 3). In transfusion parenchyma the largest concentrations of $\mathrm{Zn}$ were detected, while in Strasburger cells the largest concentrations found were those of $\mathrm{P}$. The largest concentration of $\mathrm{Si}$ in the transfusion tissues at the tip of the white pine needle, and substantial concentrations of $\mathrm{Al}$ in the epidermis of the needle base and in the transfusion tissue along the needle (Hodson and Sangster 2002), was not supported by our observation that $\mathrm{Al}$ and $\mathrm{Si}$ were evenly distributed in the Scots pine needle tissues (Figs. 2, 3, 4, 5). It may as well be, that the location of our cross section may be decisive of this observations, as the tips, as the endpoint of the transpiration stream are believed to be largest deposition areas of nitrogen, $\mathrm{B}$ and $\mathrm{Al}$ in Scots pine needles from uncontaminated sites (Giertych et al. 1997). By contrast, concentrations of Mg, $\mathrm{K}, \mathrm{S}, \mathrm{Zn}$ and Ni decreased from the base of the needle to 

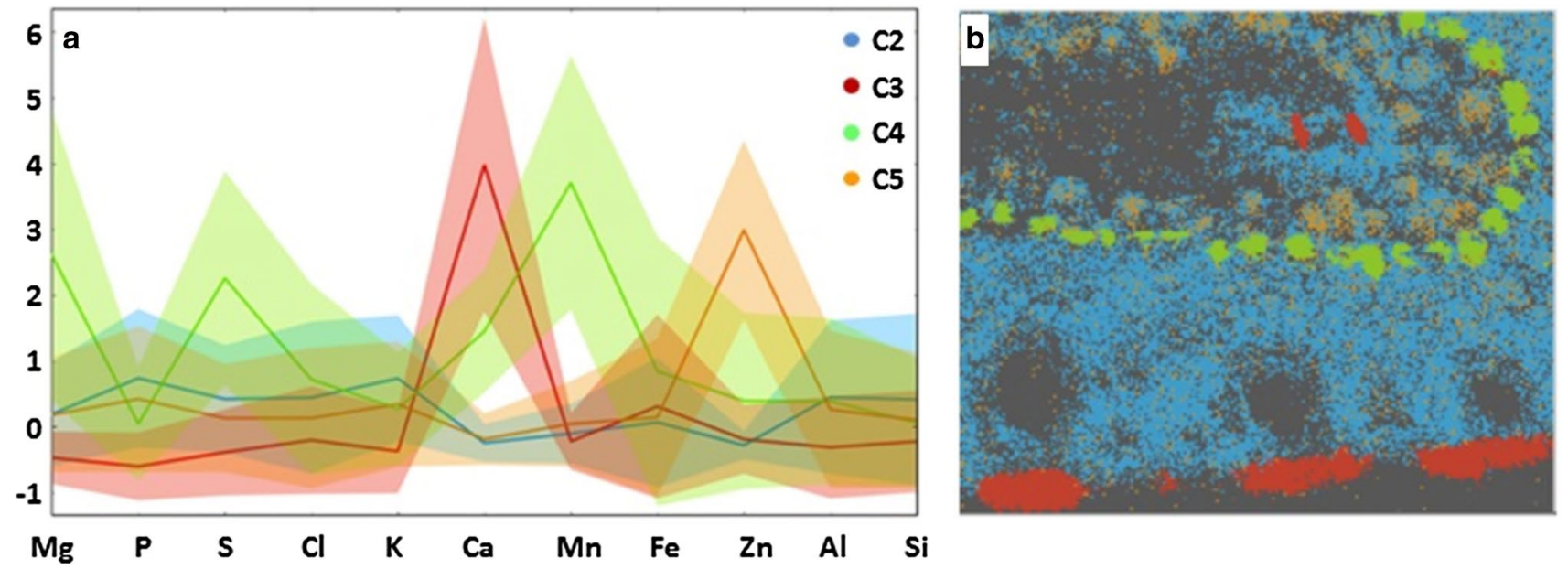

Fig. 6 Element profile plot (a) and hyperspectral image (b) depicting four clusters of elemental profiles in Scots pine needle tissues and one cluster belonging to the background (grey in b). Cluster 2 (C2) in blue depicts mesophyll, xylem, phloem, transfusion tracheids and
Strasburger cells, cluster 3 (C3) in red depicts epidermis, cluster 4 (C4) in green depicts endodermis and cluster 5 (C5) in orange depicts transfusion parenchyma

belonged to $\mathrm{Mg}, \mathrm{Mn}$ and $\mathrm{S}$. These four clusters can be used uniquely to identify elemental signatures of tissues in Scots pine needles.

discrepancy between bulk profile of the elements (Table and the element profiles obtained by micro-PIXE on needle cross section (Fig. 6), particularly for $\mathrm{Mg}, \mathrm{S}, \mathrm{Cl}, \mathrm{Mn}, \mathrm{Al}$ and Si concentrations. To fully support these observations, element distribution maps of cross-sections at the tip and on the base of needles should also be evaluated.

\section{Clustering of element profiles}

Hitherto, tissue-specific distribution of a single element was discussed, even if it was clear that each tissue could be described by a combination of elements. To separate tissues based on overall element profile of a particular tissue, k-means clustering method on $z$-normalised concentrations in each tissue was performed. This approach resulted in four distinctive clusters in the needle tissue (Fig. 6), while one cluster (C1) belonged to the background. Clusters with centroid values for particular elements above zero were considered to be rich in that element(s). Element profile of cluster 2 (C2), which is depicted in blue in Fig. 6a, b differentiated mesophyll, xylem, phloem, transfusion tracheids and Strasburger cells from other tissues; the largest centroid in this cluster belonged to K. Element profile of cluster 3 (C3), which is depicted in red in Fig. 6a, b, differentiated epidermis from other tissues; the largest centroid in this cluster belonged to $\mathrm{Ca}$. Element profile of cluster 4 (C4), which is depicted in green in Fig. 6a, b differentiated transfusion parenchyma from other tissues; the largest centroid in this cluster belonged to Zn. Element profile of cluster 5 (C5), which is depicted in orange in Fig. 6a, b, differentiated endodermis from other tissues, the largest centroids in this cluster

\section{Conclusions}

Cross-sections of Scots pine needles were mapped using micro-particle-induced X-ray emission to investigate distribution of elements in a quantitative manner. Tissue-specific distribution maps and concentrations revealed conspicuous allocation of $\mathrm{Mg}, \mathrm{S}$ and $\mathrm{Mn}$ to endodermis and of $\mathrm{Ca}$ to epidermis. Detailed analysis on the transfusion tissues enabled us to assign allocation of $\mathrm{Zn}$ to transfusion parenchyma, $\mathrm{Mn}$ and $\mathrm{K}$ to phloem, $\mathrm{Mg}$ to xylem and $\mathrm{P}$ to Strasburger cells. Because mesophyll occupies the largest proportion of the needle, the largest proportion of the majority of elements studied was found in this tissue. The only exceptions were $\mathrm{Ca}$ (in epidermis) and Mn (in endodermis). Results obtained significantly advance our current understanding of element allocation in needles and are anticipated to complement structural and functional knowledge of needle tissues.

Author contribution statement PP helped with acquiring funding for sample analyses, prepared the samples, processed results and wrote the manuscript; EB and PB acquired funding for sample analyses, designed the experiment and collected the samples; AK performed the microscopy analysis; MK, PV and PP performed micro-PIXE analysis and spectra processing; BB performed ICP-MS analysis; MR 
and KVM helped with manuscript writing. All authors gave final approval for publication.

Acknowledgements This work was supported by the European Community as an Integrating Activity 'Support of Public and Industrial Research Using Ion Beam Technology (SPIRIT)' under EC contract no. 227012. Support of Slovenian Research Agency for the research projects J7-0352 and N7-0077, research programmes P1-0112 and P1-0212, and research infrastructure of Microanalytical centre is acknowledged. Gašper Kukec-Mezek and Luka Jeromel are acknowledged for the initial micro-PIXE spectra processing.

\section{Compliance with ethical standards}

Conflict of interest The authors declare that they have no conflict of interest.

Open Access This article is distributed under the terms of the Creative Commons Attribution 4.0 International License (http://creativeco mmons.org/licenses/by/4.0/), which permits unrestricted use, distribution, and reproduction in any medium, provided you give appropriate credit to the original author(s) and the source, provide a link to the Creative Commons license, and indicate if changes were made.

\section{References}

Abràmoff MD, Magalhães PJ, Sunanda RJ (2004) Image processing with ImageJ. Biophotonics Int 11:36-42

Barbosa JZ, Constantino V, Zanette F et al (2017) Soil fertility affects elemental distribution in needles of the conifer Araucaria angustifolia: a microanalytical study. CERNE 23:257266. https://doi.org/10.1590/0104776020172302313

Bertolotti G, Gialanella S (2014) Review: use of conifer needles as passive samplers of inorganic pollutants in air quality monitoring. Anal Methods 6:6208-6222. https://doi.org/10.1039/c4ay0 $0172 \mathrm{a}$

Brække F, Salih N (2002) Reliability of foliar analyses of Norway spruce stands in a Nordic gradient. Silva Fenn 36:489-504. https ://doi.org/10.14214/sf.540

Bromfield SM, Cumming RW, David DJ, Williams CH (1983) Change in soil $\mathrm{pH}$, manganese and aluminium under subterranean clover pasture. Aust J Exp Agric 23:181-191

Carvalho MR, Losada JM, Niklas KJ (2018) Phloem networks in leaves. Curr Opin Plant Biol 43:29-35. https://doi.org/10.1016/j. pbi.2017.12.007

Conn S, Gilliham M (2010) Comparative physiology of elemental distributions in plants. Ann Bot 105:1081-1102. https://doi. org/10.1093/aob/mcq027

Detterbeck A, Pongrac P, Rensch S et al (2016) Spatially resolved analysis of variation in barley (Hordeum vulgare) grain micronutrient accumulation. New Phytol 211:1241-1254. https://doi. org/10.1111/nph.13987

Donaldson L, Williams N (2018) Imaging and spectroscopy of natural fluorophores in pine needles. Plants 7:10. https://doi.org/10.3390/ plants7010010

Dou C-M, Fu X-P, Chen X-C et al (2009) Accumulation and detoxification of manganese in hyperaccumulator Phytolacca americana. Plant Biol 11:664-670. https://doi.org/10.111 $1 / j .1438-8677.2008 .00163 . x$
Fernando DR, Lynch JP (2015) Manganese phytotoxicity: new light on an old problem. Ann Bot 116:313-319. https://doi.org/10.1093/ $\mathrm{aob} / \mathrm{mcv} 111$

Fink S (1991a) Comparative microscopical studies on the patterns of calcium oxalate distribution in the needles of various conifer species. Bot Acta 104:306-315. https://doi. org/10.1111/j.1438-8677.1991.tb00235.x

Fink S (1991b) The micromorphological distribution of bound calcium in needles of Norway spruce (Picea abies (L.) Karst). New Phytol 119:33-40. https://doi.org/10.1111/j.1469-8137.1991.tb01005.x

Franceschi VR, Nakata PA (2005) Calcium oxalate in plants: formation and function. Annu Rev Plant Biol 56:41-71. https://doi. org/10.1146/annurev.arplant.56.032604.144106

Giertych M, de Temmerman L, Rachwal L (1997) Distribution of elements along the length of Scots pine needles in a heavily polluted and a control environment. Tree Physiol 17:697-703

Hawkesford M, Horst W, Kichey T et al (2012) Functions of macronutrients. In: Marschner P (ed) Marschner's mineral nutrition of higher plants, 3rd edn. Elsevier, San Diego, pp 135-189

Hayes PE, Clode PL, Oliveira RS, Lambers H (2018) Proteaceae from phosphorus-impoverished habitats preferentially allocate phosphorus to photosynthetic cells: an adaptation improving phosphorus-use efficiency. Plant Cell Environ 41:605-619. https://doi. org/10.1111/pce.13124

Hodson MJ, Sangster AG (1998) Mineral deposition in the needles of white spruce [Picea glauca (Moench.) Voss]. Ann Bot 82:375385. https://doi.org/10.1006/anbo.1998.0694

Hodson MJ, Sangster AG (2002) X-ray microanalytical studies of mineral localisation in the needles of white pine (Pinus strobus L.). Ann Bot 89:367-374

Ingestad T (1962) Macro element nutrition of pine, spruce, and birch seedlings in nutrient solutions. Statens skogsforskningsinstitut, Stockholm

Kavvadias V, Miller H (1999) Manganese and calcium nutrition of Pinus sylvestris and Pinus nigra from two different origins. I Manganese For 72:147-155

Kuang YW, Wen DZ, Zhou G, Liu SZ (2007) Distribution of elements in needles of Pinus massoniana (Lamb.) was uneven and affected by needle age. Environ Pollut 145:730-737. https://doi. org/10.1016/j.envpol.2006.05.033

Lamppu J, Huttunen S (2003) Relations between Scots pine needle element concentrations and decreased needle longevity along pollution gradients. Environ Pollut 122:119-126. https://doi. org/10.1016/S0269-7491(02)00274-9

Leegood RC (2008) Roles of the bundle sheath cells in leaves of C3 plants. J Exp Bot 59:1663-1673. https://doi.org/10.1093/jxb/ erm335

Lersten NR (1997) Occurrence of endodermis with a casparian strip in stem and leaf. Bot Rev 63:265-272

Liesche J, Schulz A (2018) Phloem transport in gymnosperms: a question of pressure and resistance. Curr Opin Plant Biol 43:36-42. https://doi.org/10.1016/j.pbi.2017.12.006

Liesche J, Martens HJ, Schulz A (2011) Symplasmic transport and phloem loading in gymnosperm leaves. Protoplasma 248:181190. https://doi.org/10.1007/s00709-010-0239-0

Lyubenova L, Pongrac P, Vogel-Mikuš K et al (2012) Localization and quantification of $\mathrm{Pb}$ and nutrients in Typha latifolia by microPIXE. Metallomics 4:333-341. https://doi.org/10.1039/c2mt0 $0179 \mathrm{a}$

Mandre M (2009) Vertical gradients of mineral elements in Pinus sylvestris crown in alkalised soil. Environ Monit Assess 159:111124. https://doi.org/10.1007/s10661-008-0616-8

Meicenheimer RD, Coffin DW, Chapman EM (2008) Anatomical basis for biophysical differences between Pinus nigra and $P$. resinosa (Pinaceae) leaves. Am J Bot 95:1191-1198. https://doi. org/10.3732/ajb.0800127 
Merilä P, Derome J (2008) Relationships between needle nutrient composition in Scots pine and Norway spruce stands and the respective concentrations in the organic layer and in percolation water. Boreal Environ Res 13:35-47

Neugebauer K, Broadley MR, El-Serehy HA et al (2018) Variation in the angiosperm ionome. Physiol Plant 163:306-322. https://doi. org/10.1111/ppl.12700

Pallon J, Auzelyte V, Elfman M et al (2004) An off-axis STIM procedure for precise mass determination and imaging. Nucl Instrum Methods Phys Res Sect B Beam Interact Mater Atoms 219220:988-993. https://doi.org/10.1016/j.nimb.2004.01.201

Pelicon P, Podaru NC, Vavpetič P et al (2014) A high brightness proton injector for the Tandetron accelerator at Jožef Stefan Institute. Nucl Instrum Methods Phys Res Sect B Beam Interact Mater Atoms 332:229-233. https://doi.org/10.1016/j.nimb.2014.02.067

Pongrac P, Kreft I, Vogel-Mikus K et al (2013) Relevance for food sciences of quantitative spatially resolved element profile investigations in wheat (Triticum aestivum) grain. J R Soc Interface 10:20130296. https://doi.org/10.1098/rsif.2013.0296

Pundytė N, Baltrénaite E, Pereira P, Paliulis D (2011) Anthropogenic effects on heavy metals and macronutrients accumulation in soil and wood of Pinus sylvestris L.. J Environ Eng Landsc Manag 19:34-43. https://doi.org/10.3846/16486897.2011.557473

Rautio P, Huttunen S (2003) Total vs. internal element concentrations in Scots pine needles along a sulphur and metal pollution gradient. Environ Pollut 122:273-289. https://doi.org/10.1016/S0269 -7491(02)00289-0

Roden JS, Canny MJ, Huang CX, Ball MC (2009) Frost tolerance and ice formation in Pinus radiata needles: ice management by the endodermis and transfusion tissues. Funct Plant Biol 36:180. https ://doi.org/10.1071/FP08247

Ryan CG (2000) Quantitative trace element imaging using PIXE and the nuclear microprobe. Int J Imaging Syst Technol 11:219-230. https://doi.org/10.1002/ima.1007

Stelzer R, Lehmann H, Kramer D, Lüttge U (1990) X-ray microprobe analyses of vacuoles of spruce needle mesophyll, endodermis and transfusion parenchyma cells at different seasons of the year. Bot Acta 103:415-423. https://doi.org/10.1111/j.1438-8677.1990. tb00183.x

Toplak M, Birarda G, Read S et al (2017) Infrared orange: connecting hyperspectral data with machine learning. Synchrotron Radiat News 30:40-45. https://doi.org/10.1080/08940886.2017.1338424

Vavpetič P, Pelicon P, Vogel-Mikuš K et al (2013) Micro-PIXE on thin plant tissue samples in frozen hydrated state: a novel addition to JSI nuclear microprobe. Nucl Instrum Methods Phys Res Sect B Beam Interact Mater Atoms 306:140-143. https://doi. org/10.1016/j.nimb.2012.12.035

Vavpetič P, Vogel-Mikuš K, Jeromel L et al (2015) Elemental distribution and sample integrity comparison of freeze-dried and frozenhydrated biological tissue samples with nuclear microprobe. Nucl Instrum Methods Phys Res Sect B Beam Interact Mater Atoms 348:147-151. https://doi.org/10.1016/j.nimb.2015.01.063

Vogel-Mikuš K, Pongrac P, Pelicon P (2014) Micro-PIXE elemental mapping for ionome studies of crop plants. Int J PIXE 24:217233. https://doi.org/10.1142/S0129083514400142

Watanabe T, Broadley MR, Jansen S et al (2007) Evolutionary control of leaf element composition in plants. New Phytol 174:516-523. https://doi.org/10.1111/j.1469-8137.2007.02078.x

White PJ, Broadley MR (2003) Calcium in plants. Ann Bot 92:487511. https://doi.org/10.1093/aob/mcg164

White PJ, Brown PH (2010) Plant nutrition for sustainable development and global health. Ann Bot 105:1073-1080. https://doi. org/10.1093/aob/mcq085

Wigoda N, Pasmanik-Chor M, Yang T et al (2017) Differential gene expression and transport functionality in the bundle sheath versus mesophyll - a potential role in leaf mineral homeostasis. J Exp Bot 68:3179-3190. https://doi.org/10.1093/jxb/erx067

Wu X, Lin J, Lin Q et al (2005) Casparian strips in needles are more solute permeable than endodermis transport barriers in roots of Pinus bungeana. Plant Cell Physiol 46:1799-1808. https://doi. org/10.1093/pcp/pci194 